\title{
Morphological description of Dipturus mennii (Chondrichthyes: Elasmobranchii: Rajidae) and its differentiation from Dipturus trachyderma
}

\author{
Renan A. Moreira'; Ulisses L. Gomes ${ }^{1,3} \&$ Marcelo R. de Carvalho ${ }^{2}$
}

\author{
1 Laboratório de Taxonomia de Elasmobrânquios, Departamento de Zoologia, Instituto de Biologia, Universidade do Estado \\ do Rio de Janeiro. Rua São Francisco Xavier 524, 20559-900 Rio de Janeiro, RJ, Brazil. \\ ${ }^{2}$ Departamento de Zoologia, Instituto de Biociências, Universidade de São Paulo. Rua do Matão, Travessa 14, 101, \\ 05508-900 São Paulo, SP, Brazil. \\ ${ }_{3}^{3}$ Corresponding author. E-mail: ulisses@uerj.br
}

\begin{abstract}
Squamation patterns and skeletal anatomy (neurocranium, visceral arches, synarcual cartilage, scapulocoracoid, puboischiadic bar, and mixopterigium) of Dipturus mennii Gomes \& Paragó, 2001 are described as a contribution to our limited knowledge of the anatomy of species of Dipturus Rafinesque, 1810. The hyoid and branchial arches, as well as the synarcual cartilage, are described for the first time in this species. We provide morphological comparisons of this species with Dipturus trachyderma (Krefft \& Stehmann, 1975), a species that may be confused with D. mennii; we further corroborate, through anatomical features, that these species warrant separate taxonomic recognition. The main differences between $D$. mennii and $D$. trachyderma were found in squamation of the nuchal and middisc region, neurocranium, pectoral girdle, and principally the clasper skeleton. The morphology of the pelvic girdle is similar in both species. Dipturus is characterized by having the ventral terminal cartilage J-shaped (as opposed to the Z-shaped ventral termina cartilage in Zearaja, whose species were, until recently, placed in Dipturus). Additional characters that may be derived for Dipturus include the anterior rostral groove and elevated rostral proportions.
\end{abstract}

KEY WORDS. Rajinae; skates; southwestern Atlantic Ocean; taxonomy.

Skates (Rajidae) of the genus Dipturus Rafinesque, 1810 are distributed worldwide and have their greatest diversity in the continental slope but are also present in deeper areas of the continental shelf (McEachran \& Miyake 1990a, b, EвERT \& Compagno 2007, Last et al. 2008). Dipturus is presently composed of some 42 valid species (SÉret 1989, Compagno 1999, 2005, LAST 2008, LAST et al. 2008, SÉRET \& LASt 2008), with several new species awaiting description. However, many species of this genus remain poorly known and require further morphological and taxonomic scrutiny, efforts typically constrained by their conservative morphology and lack of adequate material for detailed comparisons. There are few comprehensive taxonomic studies of Dipturus (Ishiyama 1958, Stehmann 1970, Hulley 1972, Last et al. 2008).

Species of Dipturus from the southwestern Atlantic Ocean have been little studied morphologically and taxonomically in comparison to other rajid genera from this region (e.g. KREFFT 1968, Krefft \& Stehmann 1974, Menni 1971, 1972a, b, 1973, Sadowsky \& Menni 1974, Figueiredo 1977, McEachran 1982, 1983, Gomes \& Paragó 2005, Carvalho et al. 2005, 2006). Five species are presently recognized as valid from the southwestern Atlantic: Dipturus teevani (Bigelow \& Schroeder, 1951), D. leptocauda
(Krefft \& Stehmann, 1975), D. trachyderma (Krefft \& Stehmann, 1975), D. mennii Gomes \& Paragó, 2001 (Dipturus diehli Soto \& Mincarone, 2001 is a junior synonym), and D. argentinensis Astarloa, Mabragaña, Hanner \& Figueroa, 2008. Dipturus chilensis (Guichenot, 1848), which also occurs in the southwestern Atlantic, was transferred to Zearaja Whitley, 1939 by LAST \& GLEDHILL (2007) in their resurrection of this genus. Additional Dipturus species that occur in the Gulf of Mexico or off northern South America (McEachran \& Carvalho 2002), and which may eventually be recorded farther south, include $D$. garricki (Bigelow \& Schroeder, 1958), D. oregoni (Bigelow \& Schroeder, 1958), D. bullisi (Bigelow \& Schroeder, 1962), and D. olseni (Bigelow \& Schroeder, 1951).

Dipturus trachyderma was originally described from off southern Argentina from a single specimen (Krefft \& STEhmanN 1975; see also Menni \& Gosztonyi 1977, Menni \& Stehmann 2000). Subsequently, Leible \& Stehmann (1987) recorded D. trachyderma off Chile and described its mixopterigium, neurocranium, scapulocoracoid, and pelvic girdle. There are no reliable records of D. trachyderma from Brazil; note that D. trachyderma of GOMES \& Picado (2001) is, in part, D. mennii. Dipturus mennii was described from adults and juveniles that were previously identi- 
fied as D. trachyderma and collected from off the states of Rio Grande do Sul to Rio de Janeiro (Gomes \& Paragó 2001). The taxonomic separation of $D$. menni from D. trachyderma is not straightforward; both species are similar and may be easily confused. According to Gomes \& PARAGó (2001) dorsal squamation patterns are of great importance in distinguishing both species, a claim that requires further corroboration.

The aim of the present paper is to morphologically describe Dipturus mennii, specifically its squamation patterns, neurocranium, branchial arches, synarcual cartilage, scapulocoracoid, pelvic girdle, and mixopterygial skeleton. By doing so, we hope to improve our understanding of the taxonomy and morphology of southwestern Atlantic species of Dipturus, further corroborating the taxonomic separation between $D$. mennii and D. trachyderma.

\section{MATERIAL AND METHODS}

Studied specimens belong to the ichthyological (UERJ) and anatomical (A. UERJ) collections of the Department of
Zoology of the Universidade do Estado do Rio de Janeiro. Two specimens (UERJ 2106, UERJ 1893) were intact prior to our study, but three (UERJ 2103, UERJ 2104, UERJ 2105) were represented only by the head and pelvic girdle, thus not all measurements and counts were recorded. Some skeletal components were hot-water macerated with added potassium carbonate to facilitate the release of flesh. Some dry skeletal components were prepared with dermestid beetles, which facilitated the observation of minute neurocranial foramina. The initials TL and DW represent, respectively, total length and disc width.

Meristic data and external measurements were taken from Leible \& Stehmann (1987), Gomes \& Picado (2001), and Gomes \& PARAGó (2001). Measurements are presented in Table I. External morphological descriptions were based on KREFFT \& STEHMANN (1975) and Leible \& Stehmann (1987). The description of the pectoral and pelvic girdles followed LeibLe (1988). Mixopterygia were described following Stehmann (1970), Hulley (1972), and Leible (1988). Gill arches were described based on EL-Toubi \& Hamdy (1959). The description of neurocranium followed EL-

Table I. Measurements (in millimeters and percentages of total length, when available) taken from specimens of $D$. mennii; all specimens are from the UERJ collection.

\begin{tabular}{|c|c|c|c|c|c|c|c|}
\hline \multirow{3}{*}{ Measurements } & \multicolumn{7}{|c|}{ Specimen number } \\
\hline & \multicolumn{2}{|c|}{1893 (male) } & \multirow{2}{*}{$\frac{2103 \text { (male) }}{\mathrm{mm}}$} & \multirow{2}{*}{$\frac{2104 \text { (female) }}{\mathrm{mm}}$} & \multirow{2}{*}{$\frac{2105 \text { (female) }}{\mathrm{mm}}$} & \multicolumn{2}{|c|}{2106 (male) } \\
\hline & $\mathrm{mm}$ & $\%$ & & & & $\mathrm{~mm}$ & $\%$ \\
\hline Total length & 950 & 100.00 & - & - & - & 1544 & 100.00 \\
\hline Disc width & 734 & 77.26 & - & - & - & 1100 & 71.20 \\
\hline Disc length & 575 & 60.50 & - & - & - & 870 & 7.50 \\
\hline Preorbital length & 203 & 21.40 & 280 & 362 & 80 & 310 & 20.10 \\
\hline Preoral length & 217 & 22.80 & 285 & 380 & 390 & 305 & 19.75 \\
\hline Prenasal length & 179 & 18.80 & 260 & 320 & 335 & 260 & 16.80 \\
\hline Head length & 335 & 35.30 & 479 & 580 & 580 & 523 & 33.90 \\
\hline Mouth width & 80 & 8.40 & 133 & 155 & 140 & 122 & 7.90 \\
\hline Internasal length & 83 & 8.70 & 120 & 140 & 135 & 123 & 8.00 \\
\hline 1st branchial slit width & 14 & 1.50 & 16 & 10 & 20 & 15 & 1.00 \\
\hline 5th branchial slit idth & 11 & 1.20 & 17 & 20 & 17 & 10 & 0.60 \\
\hline Distance between 1st branchial slits & 142 & 14.94 & 210 & 260 & 245 & 215 & 13.90 \\
\hline Distance between 5 th branchial slits & 90 & 9.50 & 120 & 170 & 162 & 143 & 9.30 \\
\hline 1st dorsal fin height & 27 & 2.80 & 45 & - & 45 & 40 & 2.60 \\
\hline Length of 1 st dorsal fin & 45 & 4.70 & 70 & - & 65 & 70 & 4.50 \\
\hline 2nd dorsal fin height & 25 & 2.60 & 45 & - & 43 & 35 & 2.30 \\
\hline 2nd dorsal fin length & 38 & 4.00 & - & - & 60 & 62 & 4.00 \\
\hline Caudal length & 382 & 40.20 & - & - & 610 & 660 & 42.70 \\
\hline Clasper outer length & 33 & 3.47 & 190 & - & - & 195 & 12.60 \\
\hline Clasper inner length & 50 & 5.26 & 277 & - & - & 305 & 19.70 \\
\hline
\end{tabular}

ZOOLOGIA 28 (1): 97-111, February, 2011 
Toubi \& Hamdy (1959), Hulley (1972), Leible \& Stehmann (1987), Leible $(1987,1988)$, and Compagno (1988). Neurocranial measurements were based on Hubbs \& Ishiyama (1968). The synarcual cartilage was described following Gomes et al. (1997).

Anatomically prepared material of Dipturus mennii is the following: UERJ 1893 (paratype), male, $961 \mathrm{~mm} \mathrm{TL}, 763 \mathrm{~mm}$ DW, southern Rio Grande do Sul state, 1996; A.UERJ 1006, sex unknown, TL and DW undetermined, southern Rio Grande do Sul state; A.UERJ 1007, sex unknown, TL and DW undetermined, southern Rio Grande do Sul state; A.UERJ 1008, male, TL and DW undetermined, southern Rio Grande do Sul state; UERJ 2103, male, TL and DW undetermined, Paranaguá (Paraná state); UERJ 2104, female, TL and DW undetermined, Paranaguá (Paraná state); UERJ 2105, female, TL and DW undetermined, Paranaguá (Paraná state); UERJ 2106, male, 1544 mm TL, 1100 mm DW, Paranaguá (Paraná state). Other material consulted for the present paper is listed in Gomes \& Paragó (2001), Gomes \& Picado (2001), and Gomes \& Costa (2003).

\section{TAXONOMY}

Dipturus mennii Gomes \& Paragó, 2001

\section{Morphological description}

Squamation. Both dorsal (Figs 1 and 2) and ventral (Fig. 3) sides are relatively smooth, with only the interbranchial region slightly rough due to the presence of minute dermal denticles that are not visible to the naked eye and hardly sensitive to the touch. The tip of the rostrum is covered with coarse thorns, and the dorsal interorbital region is rough with very small dermal denticles that do not form a specific pattern (Fig. 2). Orbital thorns vary from six to 12 and contour the orbits, making it difficult to distinguish antorbital from interorbital thorns. No postorbital thorns are present (Fig. 2). There are two to seven spiracular thorns, five to seven nuchal thorns, one to four suprascapular thorns that may vary in the same specimen, and there is a single continuous row of 18 to 25
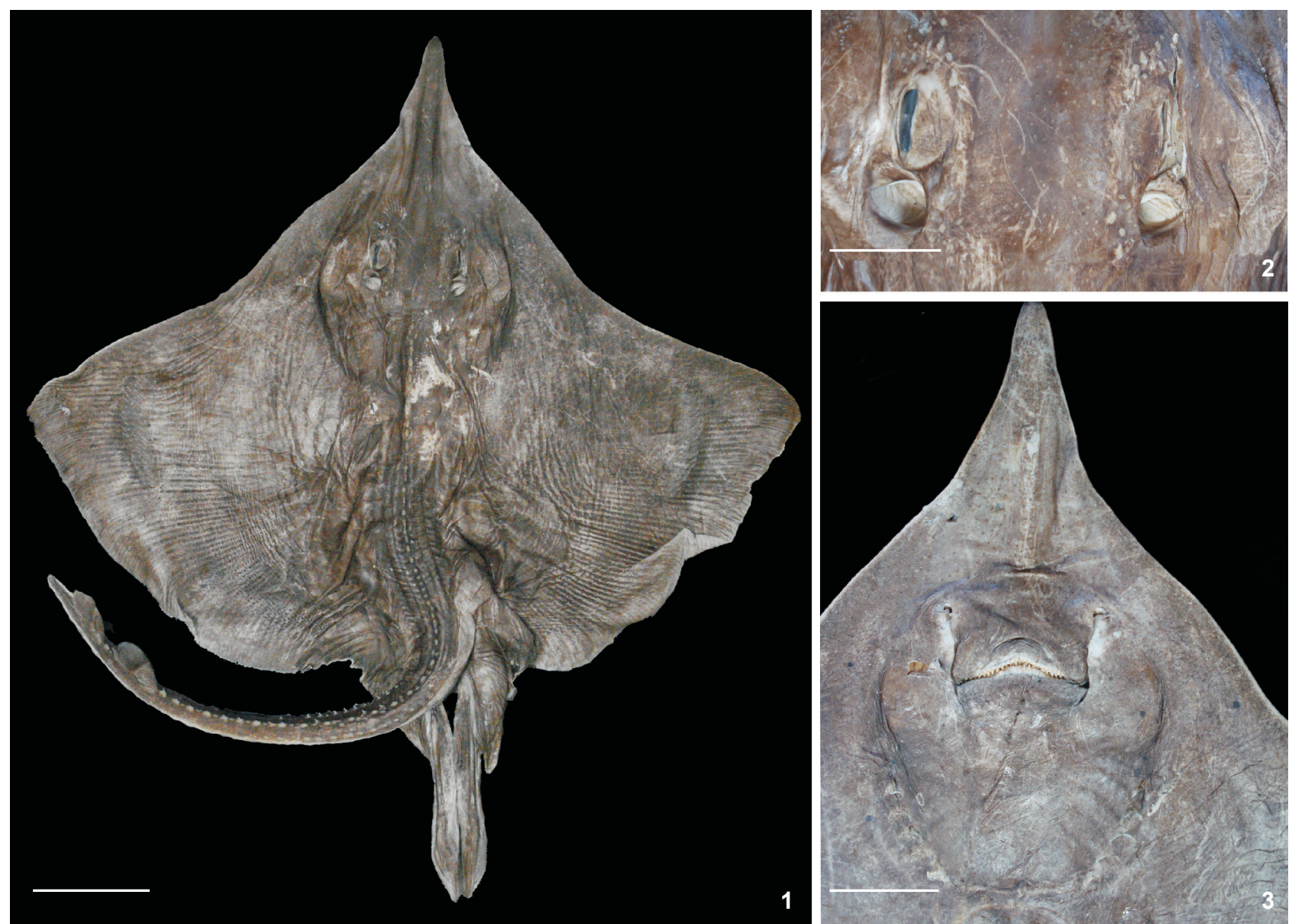

Figures 1-3. Dipturus mennii, UERJ 2106: (1) dorsal view; (2) interorbital region; (3) mouth and interbranchial region. Scale bars: $1=200 \mathrm{~mm}, 2=50 \mathrm{~mm}, 3=100 \mathrm{~mm}$. 
mediodorsal thorns (Tabs II and III). The sexually mature male examined presented 56 alar thorns on the left side and 53 on the right, arranged in three distinct rows. In the caudal region, the males present three rows of thorns and females have five. The mediocaudal row is composed of 25 to 43 thorns, the laterocaudal thorns vary from six to 24 on the left side and from seven to 26 on the right side; laterocaudal thorns do not reach the tail end. The second row of laterocaudal thorns (semilateral thorns) in females has 8 thorns on each side. The interdorsal space presents one to three thorns (Tab. II).

Neurocranium. Dipturus mennii presents a long and stout rostrum (R) (almost 66\% of neurocranial TL; see Table IV for neurocranial measurements). A narrow rostral appendix (RA) is present and is much less calcified than the rostrum. The rostral appendix is perforated by a series of small rostral appendix foramina (new term) (RAF) (Fig. 4) for the passage of the superficial ophthalmic branches of the trigeminal-facial nerves (V + VII). The anterior fontanelle (AF) is elongated and oval, presenting two regions, the anterior precerebral portion (above the rostrum) and the posterior supracranial portion (above the skull roof). The anterior margin of the precerebral fontanelle is not clearly defined due to a narrow anterior rostral groove (RG) that extends in anteriorly toward the rostral apex. The limit of the anterior groove and the anterior fontanelle is marked by the pres-

Table II. Thorn counts in specimens of $D$. mennii $(\mathrm{R}=$ right, $\mathrm{L}=$ left); all five specimens are from the UERJ collection.

\begin{tabular}{|c|c|c|c|c|c|}
\hline & \multicolumn{3}{|c|}{ Male } & \multicolumn{2}{|c|}{ Female } \\
\hline & 1893 & 2103 & 2106 & 2104 & 2105 \\
\hline Nuchal & 5 & 5 & 7 & 5 & 6 \\
\hline Suprascapular & $L=2 / R=2$ & $L=4 / R=2$ & $L=4 / R=3$ & $L=1 / R=1$ & $\mathrm{~L}=3 / \mathrm{R}=4$ \\
\hline Mediodorsal & 18 & - & 25 & - & - \\
\hline Caudal row & 3 & 3 & 3 & 5 & 5 \\
\hline Mediocaudal & 25 & 29 & 43 & - & 30 \\
\hline Lateral caudal rows & $L=6 / R=7$ & $\mathrm{~L}=11 / \mathrm{R}=11$ & $L=14 / R=12$ & - & $L=24 / R=26$ \\
\hline Semilateral caudal rows & - & - & - & - & $\mathrm{L}=8 / \mathrm{R}=8$ \\
\hline Interdorsals & 1 & 2 & 3 & - & 3 \\
\hline Alar & - & - & $L=56 / R=53$ & - & - \\
\hline Orbital & $L=6 / R=7$ & $\mathrm{~L}=8 / \mathrm{R}=7$ & $\mathrm{~L}=12 / \mathrm{R}=10$ & $\mathrm{~L}=11 / \mathrm{R}=11$ & $\mathrm{~L}=11 / \mathrm{R}=10$ \\
\hline Spiracular & $L=2 / R=3$ & $\mathrm{~L}=4 / \mathrm{R}=4$ & $\mathrm{~L}=4 / \mathrm{R}=7$ & $L=4 / R=4$ & $L=6 / R=5$ \\
\hline
\end{tabular}

Table III. Comparison of thorn counts in specimens of D. mennii and D. trachyderma. (R) Right, (L) left.

\begin{tabular}{|c|c|c|c|c|}
\hline & \multicolumn{2}{|c|}{ Dipturus mennii } & \multicolumn{2}{|c|}{ Dipturus trachyderma * } \\
\hline & Male & Female & Male & Female \\
\hline Nuchal & $5-7$ & $5-6$ & 0 & 0 \\
\hline Suprascapular & $L=2-4 / R=2-3$ & $L=1-3 / R=1-4$ & 0 & 0 \\
\hline Mediodorsal & $18-25$ & - & 0 & 0 \\
\hline Caudal row & 3 & 5 & 3 & 5 \\
\hline Mediocaudal & $25-43$ & 30 & $24-43$ & $24-24$ \\
\hline Lateral caudal rows & $\mathrm{L}=6-14 / \mathrm{R}=7-12$ & $\mathrm{~L}=24 / 26$ & $\mathrm{~L}=4-26$ & $\mathrm{~L}=20-30$ \\
\hline Semilateral caudal rows & - & $\mathrm{L}=8 / \mathrm{R}=8$ & - & $\mathrm{L}=14-30$ \\
\hline Interdorsal & $1-3$ & 3 & $0-4$ & $1-3$ \\
\hline Alar & $\mathrm{L}=56 / \mathrm{R}=53$ & 0 & $\mathrm{~L}=46 / \mathrm{R}=48$ & 0 \\
\hline Orbital & $\mathrm{L}=6-12 / \mathrm{R}=7-10$ & $\mathrm{~L}=11 / \mathrm{R}=10-11$ & $\mathrm{~L}=0-12 / \mathrm{R}=0-12$ & $\mathrm{~L}=0-7 / \mathrm{R}=0-7$ \\
\hline Spiracular & $\mathrm{L}=2-4 / \mathrm{R}=3-7$ & $L=4-6 / R=4-5$ & 0 & 0 \\
\hline
\end{tabular}

* Data from Leible \& Stehmann (1987). 


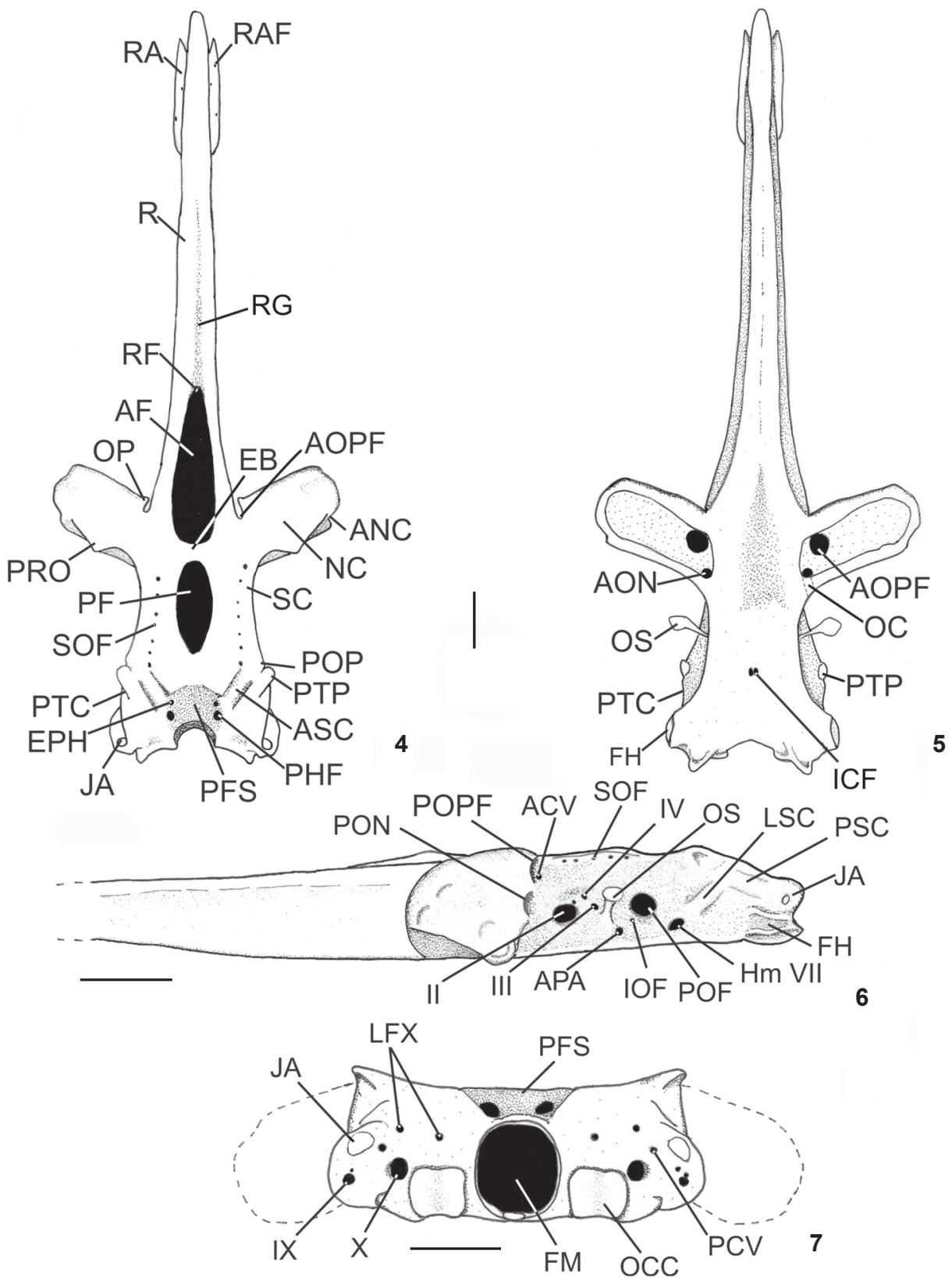

Figures 4-7. Neurocranium of D. mennii (UERJ 2104), in dorsal (4), ventral (5), lateral (6), and occipital (7) views. (ACV) anterior cerebral vein foramen, (AF) anterior fontanelle, (ANC) antorbital condyle, (AON) antorbital foramen, (AOPF) anterior ophthalmic foramen, (APA) afferent pseudobranchial artery foramen, (ASC) anterior semicircular canal, (ICF) internal carotid foramen, (EB) epiphysial bridge, (EPH) endolymphatic foramen, (FH) facet for hyomandibular cartilage, (FM) foramen magnum, (RG) rostral groove, (Hm VII) hyomandibular branch foramen, (IOF) internal orbital foramen, (JA) jugal arch, (LSC) lateral semicircular canal, (LFX) lateral foramen of the vagus nerve, (NC) nasal capsule, (OC) orbitonasal canal, (OCC) occipital condyle, (OP) ophthalmic process, (OS) optic stalk, (PCV) posterior cerebral vein foramen, (PF) posterior fontanelle, (PFS) parietal fossa, (PHF) perilymphatic foramen, (POF) prootic foramen, (PON) posterior orbitonasal foramen, (POP) postorbital process, (POPF) posterior ophthalmic foramen, (PRO) preorbital process, (PSC) posterior semicircular canal, (PTC) pterotic crest, (PTP) pterotic process, (R) rostrum, (RA) rostral appendix, (RAF) rostral appendix foramen, (RF) rostral foramen, (SC) supraorbital crest, (SOF) supraophthalmic foramen, (II) optic nerve foramen, (III) oculomotor nerve foramen, (IV) trochlear nerve foramen, (IX) glossopharyngeal nerve foramen, $(X)$ vagus nerve foramen. Scale bars: 4-5 = 40 $\mathrm{mm}, 6-7=30 \mathrm{~mm}$. 
Table IV. Neurocranial measurements $(\mathrm{mm})$ taken from specimens of $D$. mennii. Percentages are in relation to neurocranial total length; all specimens are from the UERJ collection.

\begin{tabular}{|c|c|c|c|c|c|}
\hline \multirow{3}{*}{ Measurements } & \multicolumn{5}{|c|}{ Specimen number } \\
\hline & \multirow{2}{*}{$\frac{1006}{\mathrm{~mm}}$} & \multicolumn{2}{|c|}{1008} & \multicolumn{2}{|c|}{2104} \\
\hline & & $\mathrm{mm}$ & $\%$ & $\mathrm{~mm}$ & $\%$ \\
\hline Neurocranium length & - & 385 & 100.00 & 480 & 100.00 \\
\hline Nasobasal length & 130 & 145 & 37.70 & 165 & 34.40 \\
\hline Rostral cartilage length & - & 240 & 62.30 & 320 & 66.70 \\
\hline Neurocranium width & 135 & 17 & 4.40 & - & - \\
\hline Interorbital width & 55 & 66 & 17.10 & 78 & 16.25 \\
\hline Rostral base width & 40 & 55 & 14.28 & 72 & 15.00 \\
\hline Anterior fontanelle width & - & 22 & 5.70 & 31 & 6.40 \\
\hline Epiphysial bridge width & - & 6 & 1.50 & 8 & 1.60 \\
\hline Posterior fontanelle length & - & 60 & 15.60 & 71 & 14.80 \\
\hline Rostral appendix length & - & - & - & 91 & 18.90 \\
\hline Appendix length width & - & - & - & 10 & 2.10 \\
\hline Width between optic capsules & 74 & 87 & 22.30 & 98 & 20.40 \\
\hline Basal plate width & 45 & 52 & 13.50 & 62 & 12.90 \\
\hline Nasal openings width & - & 32 & 8.30 & 33 & 6.90 \\
\hline Internasal width & 45 & 48 & 12.50 & 60 & 12.50 \\
\hline
\end{tabular}

ence of a small rostral foramen (new term) (RF). There is a narrow epiphysial bridge (EB) separating the anterior fontanelle from the posterior fontanelle (PF), which is completely supracranial and proportionally smaller and less oval than the anterior fontanelle (Fig. 4). At the anterior extremity of the neurocranial roof there is the posterior margin of the anterior fontanelle. Ventrally, the neurocranial basal plate is narrow anteriorly between the nasal capsules, but becomes wider posteriorly (Fig. 5). In the center of the basal plate is the foramen for the passage of the internal carotid artery (ICF) (Fig. 5), which may have two openings or may lie within a depression which contains both openings (more specimens should be observed in order to check the state of this character). The nasal capsule (NC) is somewhat rectangular and anteriorly arched (Fig. 4). At the junction of the nasal capsule with the base of the rostrum is the anterior ophthalmic foramen (AOPF) (Figs 4-6). The anterior ophthalmic foramen is protected by a small protuberance, the ophthalmic process (OP, new term) (Fig. 4). In D. menni, the anterior ophthalmic foramen has an unusual shape, as it is not completely enclosed, resembling a groove that opens into the nasal capsule (Figs 4-6). On the lateral side of the nasal capsule, directed outwardly, there is the antorbital condyle (ANC) that articulates with the antorbital cartilage. The antorbital cartilage contains a circular foramen for the passage of a nerve that innervates ampullae of Lorenzini in the anterolatral head region. Dorsally on the nasal capsule is the well-developed and triangular preorbital process (PRO) that is continuous with the supraorbital crest (SC) (Fig. 4). The lateral skull roof is dorsally limited by the supraorbital crest pierced by a series of supraophthalmic foramina (SOF) (Figs 4 and 6) which vary in number among different specimens, and may even vary between different sides of the same individual; the posterior-most foramina are more developed. Continuous with the crest is the postorbital process (POP), which is not very pronounced and which limits the posterior roof of the neurocranium. The orbital region (Fig. 6) is located posterior to the posterior wall of the nasal capsule, which is pierced by two foramina, the posterior orbitonasal foramen (PON) and posterior ophthalmic (POPF) foramina. The orbitonasal canal (OC) follows of the posterior orbitonasal foramen inside the nasal capsule, opening in anterior orbitonasal foramen (AON). Dorsally to the posterior ophthalmic foramen is the small foramen for anterior cerebral vein (ACV). Lateral to the posterior orbitonasal foramen is a large and slightly elliptical foramen for the optic nerve (II), and almost at the same level but situated more posteriorly is the large prootic foramen (POF), which is slightly more rounded than the optic foramen. The hyomandibular branch of the facial nerve (HmVII) is located posteriorly and slightly more ventrally to the prootic foramen. A small foramen for the internal orbital vein (IOF) is positioned just anteroventrally to the prootic foramen and slightly dorsal to the foramen for the afferent pseudobranchial artery (APA), which is near the ventral limit of the otic capsule. Dorsal to the optic 
nerve foramen are two small openings for the passage of the trochlear nerve (IV). Anteroventral to the rather large optic stalk (OS) is the foramen for the oculomotor nerve (III). The optic stalk is a flexible and distally flat cartilage situated halfway between the optic nerve and prootic foramina at orbital midlength (Fig. 6). The otic region may present individual variations in the configuration of the ridges formed by the anterior (ASC), posterior (PSC) and lateral semicircular canals (LSC) which are more clearly marked in some specimens. Dorsally, the parietal fossa (PFS) presents foramina that vary in size and position in each individual. The perilymphatic foramen (PHF) is always greater than the endolymphatic foramen (EPH). Delimiting the otic region dorsolaterally is a rounded pterotic process (PTP) (Figs 4 and 5), continuous with a low pterotic crest (PTC) (Figs 4 and 5) itself weakly visible. The occipital region (Fig. 7) is subrectangular with a large circular foramen magnum (FM) between the occipital condyles (OCC), which in turn are ventral to two small foramina for the lateral branch of the vagus nerve (LFX). Between the occipital condyle and the jugal arch (JA) is the vagus nerve foramen (X), itself below the foramen of the posterior cerebral vein (PCV). Just below the jugal arch is the glossopharyngeal nerve foramen (IX).

Synarcual cartilage. The synarcual cartilage is subrectangular, being wider posteriorly at the suprascapulae (SE), followed by the lateral stay (LS) (Figs 8-10). The anterior margin of the suprascapula is slightly concave and laterally its articular surface is horizontal and broad, parallel to the synarcual base (Fig. 10). The lateral stay is triangular and widest posteriorly. Anterior to the lateral stay side is a long and subrectangular anterior lateral flap (ALF) that has a large basal foramen (BF) medially situated (Figs 8-10). The posterior lateral flap (PLF) is posterior to the lateral stay but is narrower than the anterior lateral stay (Fig. 10). The odontoid process (OTP) in the anterior extremity of the synarcual is slightly oval with a prominent odontoid collar (OTC) that completely borders the aperture (Figs 8 and 9). The intermuscular septum is divided into two regions, anterior and posterior. The anterior intermuscular septum (AIS) extends across the dorsal region of the synarcual from the odontoid process to the suprascapula. The posterior intermuscular septum (PIS) continues posteriorly from the suprascapulae and tapers caudally (Fig. 8). Small, parallel, dorsal and ventral spinal foramina (DSF and VSF) (Figs 8 and 10) occur throughout almost the entire extent of the lateral side of the synarcual cartilage. In lateral view these foramina are covered by the anterior lateral flap and partially by the posterior lateral flap (Fig. 10).

Hyoid and branchial arches. Dorsally in Dipturus mennii, the pseudohyoid cartilage (PSH) is situated at the same level, and placed anteriorly to the five subsequent epibranchials (EP 1-5) (Fig. 11). The epibranchials are subrectangular and similar in shape (Fig. 11). Slender dorsal extrahyal (DEH) and dorsal extrabranchial (DEB) cartilages are found external to the pseudohyoid and each epibranquial element, respectively, ex-
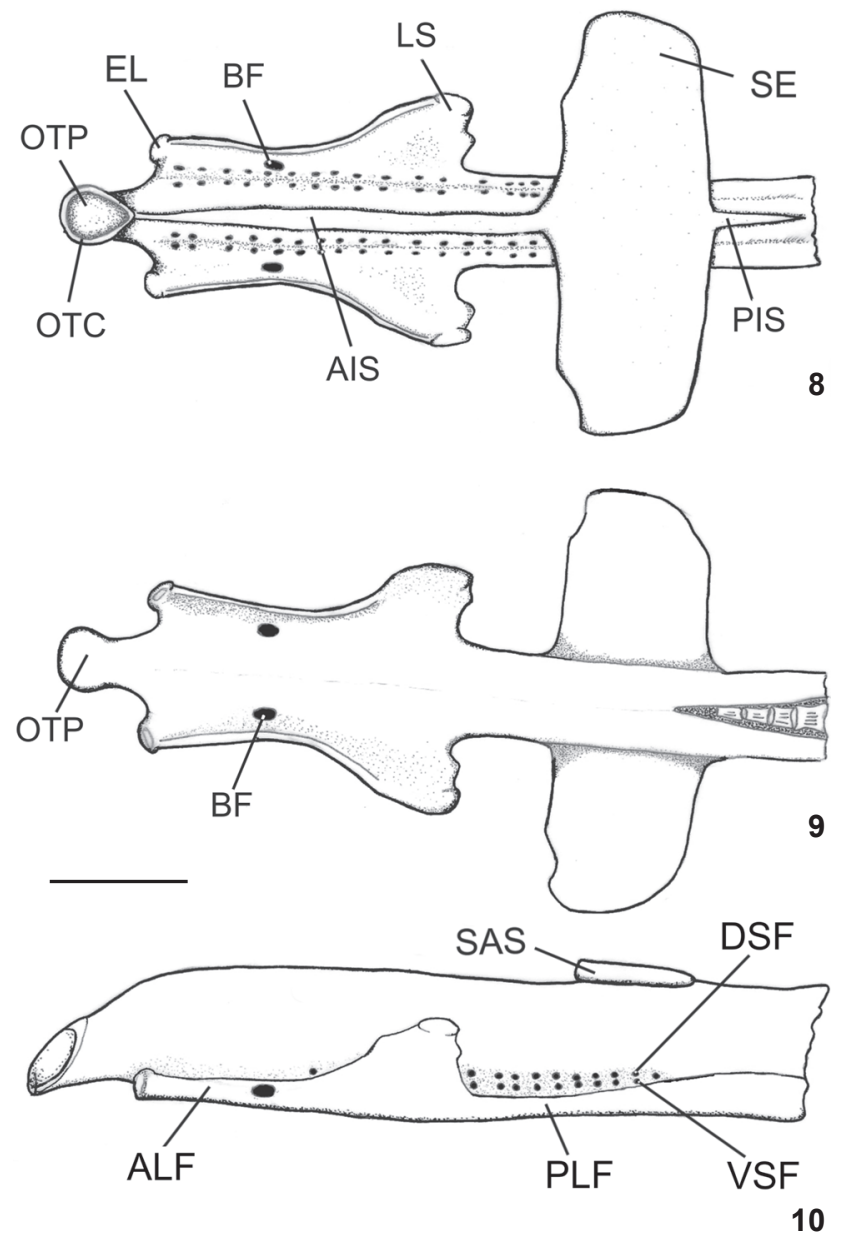

Figures 8-10. Synarcual cartilage of $D$. mennii (UERJ 2104), in dorsal (8), ventral (9), and lateral (10) views. (AIS) anterior intermuscular septum, (ALF) anterior lateral flap, (BF) basal foramen, (DSF) dorsal spinal foramen, (LE) lateral extension, (LS) lateral stay, (OTC) odontoid collar, (OTP) odontoid process, (PIS) posterior intermuscular septum, (PLF) posterior lateral flap, (SAS) articular surface for suprascapula, (SE) suprascapula, (VSF) ventral spinal foramen. Scale bar: $30 \mathrm{~mm}$.

cept for the fifth epibranchial in which extrabranchials are absent (Fig. 11). Articulated dorsally to each epibranchial are the posteriorly oriented pharyngobranchials (PHB). The first pharyngobranchial is triangular. The second and third pharyngobranchials are similar in size and shape, being elongated and tapering distally. The fourth and fifth pharyngobranchials are fused together along with their respective epibranchial elements (Fig. 11).In the ventral branchial region, ceratobranchials 1 to 4 (CB) are similarly shaped (Fig. 12), whereas ceratobranchial 5 (CB5) is relatively longer and more slender and articulates with the pectoral girdle posteriorly. The 

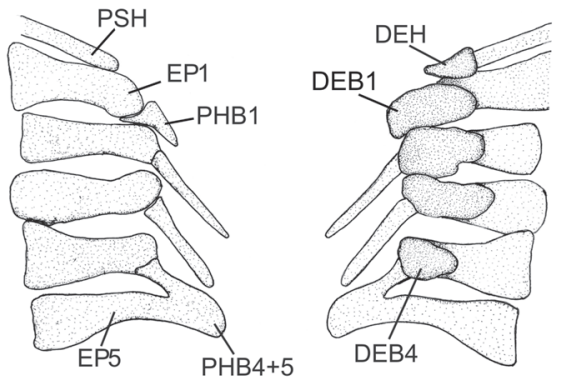

11

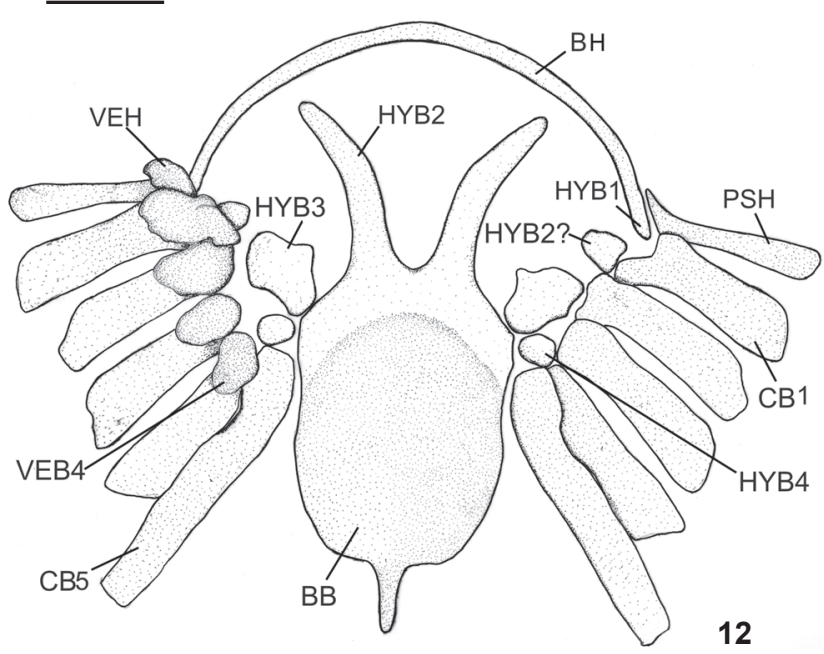

Figures 11-12. Branchial arches of D. mennii (UERJ 2104), in dorsal (11) and ventral (12) views. (BH) basihyal arch, (BB) basibranchial, (DEB1) dorsal extrabranchial 1, (DEB4) dorsal extrabranchial 4, (DEH) dorsal extrahyal, (HYB1) hypobranchial 1, (HYB2) hypobranchial 2, (HYB3) hypobranchial 3, (HYB4) hypobranchial 4, (HYB2?) possible hypobranchial 2 segment, (EP1) epibranchial 1, (EP5) epibranchial 5, (PHB1) pharyngobranchial 1, (PHB4+5) pharyngobranchial 4+5, (PSH) pseudohyoid, (VEB4) ventral extrabranchial 4, (VEH) ventral extrahyal. Extrabranchial elements removed from left side in 11, and right side in 12 . Scale bars: $11=40 \mathrm{~mm}, 12=20 \mathrm{~mm}$.

proximal extremity of the first ceratobranchial cartilage is bifurcated, and the longest segment is in contact with the second ceratobranchial cartilage and a cartilage identified as a possible additional hypobranchial cartilage (HYB2? in Fig. 12). As in the dorsal elements, each ventral extrabranchial (VEB) covers its respective ceratobranchial, except for ceratobranchial 5 . The ventral portion of the pseudohyoid also has a corresponding ventral extrahyal element (VEH) (Fig. 12). Posterior to Meckel's cartilage is the basihyal cartilage $(\mathrm{BH})$, the ends of which are fused to the first hypobranchials (HYB1). Medially there are three hypobranchial cartilages and a large basibranchial cartilage (BB) (or basibranchial copula, which is fused to hypobranchial 2 cartilages, HYB2). The basibranchial copula is dorsoventrally flattened, broad, and projects posteriorly as a slender extension. The second hypobranchial element has two curved anterior extensions that almost reach the bashyal arch. Immediately lateral to the second hypobranchial is the third hypobranchial cartilage (HYB3), which is somewhat asymmetrical in relation to its antimere, and positioned at the same level of ceratobranchials 2 and 3. The fourth hypobranchial (HYB4) is circular and located in between hypobranchial 3, ceratobranchials 4 and 5, and the base of hypobranchial 2 (Fig. 12).

Scapulocoracoid. The pectoral girdle is rectangular, limited anteriorly by a rounded procondyle (PR) and posteriorly by the more elongated metacondyle (MT). Between the procondyle and metacondyle there is a truncated and elongated mesocondyle (MS) (Fig. 13). The distance between the procondyle and mesocondyle is smaller than the distance between the mesocondyle and metacondyle. In the dorsal region there is a small but clearly visible scapular process (SCP). There are 17 small protuberances along almost all of the ventral extension of the girdle, below the condyles. The rear corner (RC) is well developed. Two large lateral fenestrae are present. The anterior fenestra (AFE) is between the mesocondyle and procondyle. It has a more circular shape and is slightly wider than the posterior fenestra. The posterior fenestra is subdivided into dorsal and ventral fenestra, separated by a long, narrow neopterygial process (NP). The posterior dorsal fenestra (PDF) is oval and about the same size as the anterior fenestra (Tab. $\mathrm{V})$. The posterior ventral fenestra (PVF) is more elliptical, dorsoventrally flattened, and is about one-fourth the height of the posterior dorsal fenestra.

Puboischiadic bar. The pelvic girdle or pubschiadic bar (Figs 14 and 15) is dorsoventrally flattened, transversely oriented, and has three to four laterally situated iliac foramina (IF). The prepelvic processes (PRP) are triangular and lateroanteriorly po-

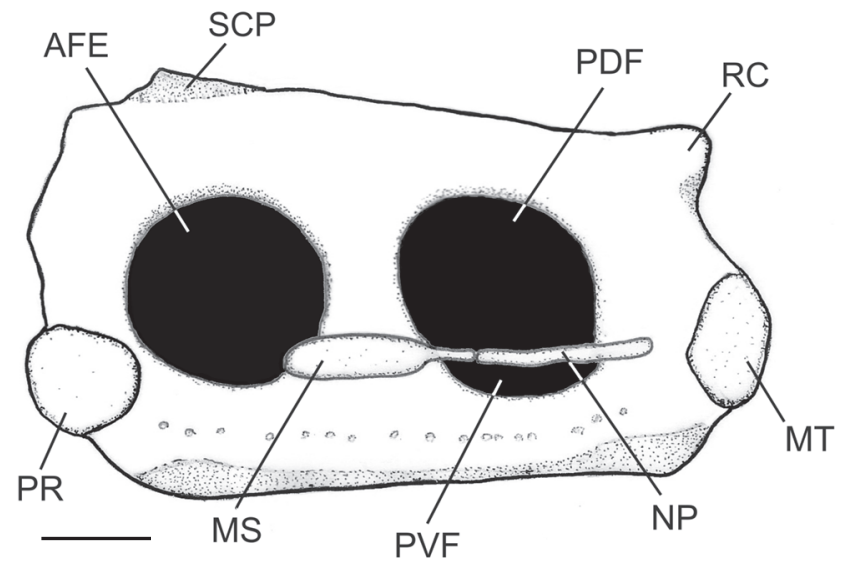

Figure 13. Lateral view of scapuloracoid of $D$. mennii (UERJ 1008). (AFE), anterior fenestra, (MS) mesocondyle, (MT) metacondyle, (NP) neopterygial process, (PDF) posterior dorsal fenestra, (PR) procondyles, (PVF) posterior ventral fenestra, (RC) rear corner, (SCP) scapular process. Scale bar: $20 \mathrm{~mm}$. 


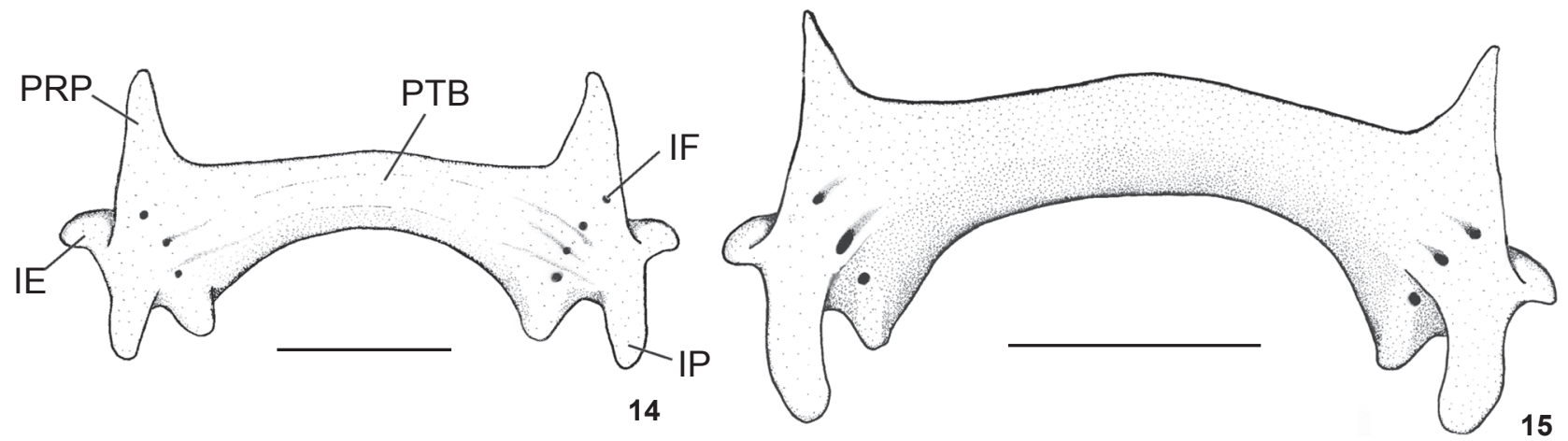

Figures 14-15. Puboischiadic bar of D. mennii: (14) dorsal view of male (UERJ 2103); (15) ventral view of female (UERJ 2105). (PRP) prepelvic processes, (PTB) transverse pelvic bar, (IE) iliac extension, (IF) iliac foramen, (IP) iliac process. Scale bars: $14=40 \mathrm{~mm}, 15=50 \mathrm{~mm}$.

Table V. Measurements ( $\mathrm{mm}$ ) of the scapulocoracoid taken from one specimen of $D$. mennii. Percentages are in relation to scapulocoracoid total length; specimen is from the UERJ collection.

\begin{tabular}{lrr}
\hline \multirow{2}{*}{ Measurements } & \multicolumn{2}{c}{ Specimen 1008 (male) } \\
\cline { 2 - 3 } & $\mathrm{mm}$ & $\%$ \\
\hline Total length & 113 & 100.00 \\
Maximum height & 66 & 58.40 \\
Premesocondyle length & 72 & 63.70 \\
Postmesocondyle length & 45 & 39.80 \\
Anterior fenestra maximum height & 33 & 29.20 \\
Anterior fenetra maximum length & 31 & 27.40 \\
Posterior dorsal fenestra height & 24 & 21.20 \\
Posterior dorsal fenestra length & 30 & 26.50 \\
Posterior ventral fenestra height & 7 & 6.10 \\
Posterior ventral fenestra length & 25 & 22.12 \\
\hline
\end{tabular}

sitioned. The well developed iliac process (IP) has a rounded extremity and extends posteriorly from the iliac region. The rounded, laterally situated iliac extension (IE) is smaller than the iliac process. There is a sexual dimorphism in the posterior part of the puboischiadic transverse bar (PTB), which is slightly less arched and relatively smaller in males (Fig. 14) than in females (Fig. 15).

Clasper. The mixopterigial (clasper) skeleton consists of three groups of cartilages: the basal, axial, and distal groups. The basal group (not described here for D. menni because they were lost in preparation) is formed by the b1, b2 (intermediate proximal segments), and $\beta$ cartilages. The axial group is represented by three fused cartilages: the axial (AX), dorsal marginal (DM), and ventral marginal (VM). The cartilages of the distal group are the dorsal terminals (DT1, DT2 and DT3), ventral terminal (VT), and accessory terminals (ACT1 and ACT2) (Figs 16 and 17).

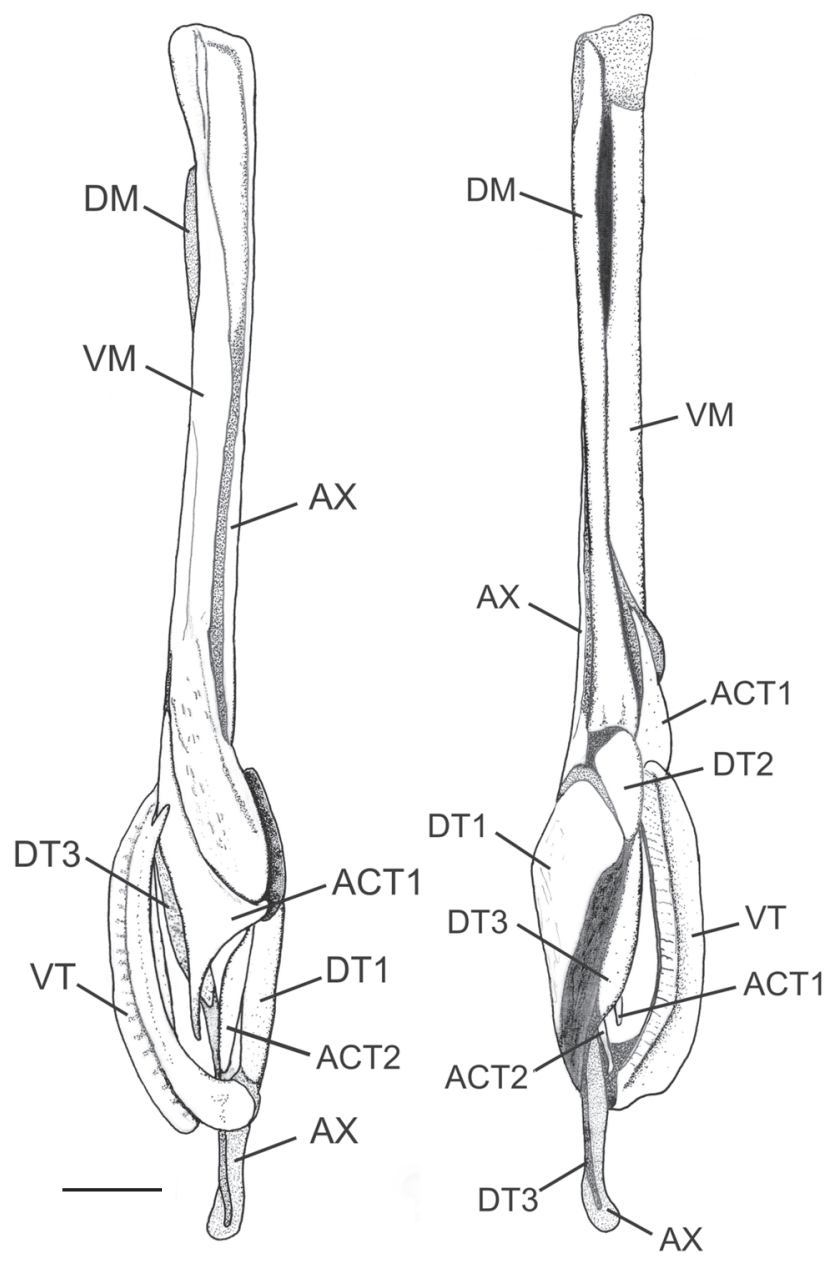

Figures 16-17. Clasper skeleton of D. mennii (UERJ 2103), in dorsal (16) and ventral (17) views. (ACT1) accessory terminal 1, (ACT2) accessory terminal 2, (AX) axial, (DM) dorsal marginal, (DT1) dorsal terminal 1, (DT2) dorsal terminal 2, (DT3) dorsal terminal 3, (VM) ventral maginal, (VT) ventral terminal. Scale bars: 16-17 $=20 \mathrm{~mm}$. 
The axial cartilage extends throughout the entire length of the mixopterigium. Its distal end is subdivided and less calcified; the medial segment suffers a slight torsion. Externally the spermatic groove is located between the dorsal and ventral marginal cartilages. The dorsal marginal cartilage (Fig. 16) extends from its articulation with the $\mathrm{b} 2$ and $\beta$ cartilages (not shown in Fig. 16) to the clasper glans region, anterior to the terminal cartilages. The ventral marginal cartilage has a rounded and expanded posterior end, and is broader than the dorsal marginal cartilage (Figs 16, 17 and 26).

The distal region of the glans presents dorsal and ventral components. The dorsal component is formed by three dorsal terminal cartilages. The dorsal terminal 1 cartilage is long and lacks the proximal shelf for the clasper dilator muscle. It is subtriagular, slightly dorsal to the dorsal terminal 2 cartilage and supported by almost the entire distal portion of the axial cartilage. The proximal region of the dorsal terminal 1 cartilage is broad, with a rounded margin, and becomes more slender distally where it is twisted and covers the distal axial region (Figs 16, 17, 20 and 21). The dorsal terminal 2 cartilage is subrectangular (Figs 16, 26 and 27), located between the dorsal terminal 1 and the distal extension of the dorsal marginal cartilage. At the distal end of the dorsal terminal 2 cartilage is the poorly calcified and short terminal bridge (TB), which reaches the dorsal terminal 3 cartilage and the distal portion of the axial cartilage (Figs 26 and 27). The dorsal terminal 3 extends distally from the dorsal terminal 2 and fuses with the axial cartilage at its less calcified portion (Figs 26 and 27).

The ventral component of the mixopterigium has the same number of components as those of the dorsal component: one ventral terminal and two acessory terminal cartilages ( 1 and 2 ). The ventral terminal cartilage (Figs 16, 17, 18 and 19) is J-shaped, with a pointed projection anteroventrally (Figs 17 and 19, see arrow) which extends about $1 / 5$ of the total length of the cartilage. The ventral and anterior aspects of the ventral terminal cartilage support the anterior segment of the acessory terminal 1 , located at the external clasper margin (Fig. 17). The accessory terminal 1 is Y-shaped (Figs 17, 24 and 25). The most elongated (anterior) branch is turned toward the outer clasper margin (Figs 16 and 17). A rod-shaped accessory terminal 2 cartilage is present articulating with the distal end of the ventral marginal cartilage; its distal end also presents a slight torsion (Figs 17, 22 and 23). This cartilage is located at almost the limit of the dorsal and ventral lobes of the mixopterigium, where it is slightly supported by the dorsal terminal 1 and accessory terminal 1 cartilages.

\section{DISCUSSION}

Our morphological investigation of D. mennii revealed additional characters that allow it to be distinguished from $D$. trachyderma (summarized in Table VI). According to LeIbLe \& Stehmann (1987), D. trachyderma is characterized by a rough dorsal and ventral surface, covered with small denticles, but lacks nuchal and mediodorsal thorns. As D. mennii has a relatively rough interbranchial region, and the rostral and interorbital regions also have coarse denticles, mistakes in the identification of both species have occurred (e.g. Gomes \& PICADo 2001). Dipturus mennii, however, is unequivocally characterized by a continuous row of thorns from the nuchal region to the first dorsal fin (we therefore confirm the observations of Gomes \& PARAGó 2001), and is much less course throughout. Below we discuss further morphological features that separate $D$. mennii from $D$. trachyderma and compare them to the morphology of other Dipturus species. Pelvic girdle morphology, however, is not useful to distinguish $D$. mennii from $D$. trachyderma. Comparisons of gill arches and synarcual cartilage were not possible due to lack of comparative data for $D$. trachyderma and other Dipturus species.

\section{Neurocranium}

The neurocranium of $D$. mennii and D. trachyderma are generally similar in proportions and in most structures. However, the neurocranium of $D$. mennii presents a unique ophthalmic process which overlies the ophthalmic foramen. In $D$. trachyderma, the ophthalmic process is missing (Leible \& Stehmann 1987). The optic foramen in D. mennii is circular compared to the elongated optic foramen of D. trachyderma, but this feature needs to be compared in more specimens of the latter species before it can be employed to distinguish it from D. mennii.

In both $D$. trachyderma and $D$. mennii there is a small narrow groove in front of the anterior fontanelle which is identified by Stehmann (1970) and Hulley (1972) as a defining generic character, being considered by IsHIHARA \& IsHIYAMA (1986) the only really useful character to distinguish Dipturus from the closely related Okamejei, which does not have this feature. This narrow groove is also not found in Zearaja, the possible sister-group of Dipturus (LAST \& GledHILl 2007). As the rostral groove is not present in other rajid taxa, its presence in Dipturus may be derived. However, Jeong \& NAKABo (2008) described Dipturus wuhanlingi based on a juvenile specimen which does not have the rostral groove. And previously, SÉRET (1989) had described adults of Dipturus crosnieri as lacking the rostral groove and, according to that author, this species exhibits other putative characters of Dipturus in accordance with the key for Dipturus and Okamejei presented by IsHiHARA (1987). The lack of the rostral groove anterior to the rostral cartilage can be a further derived character for these species, or perhaps they are basal to other species of Dipturus; in any case they do not deny the rostral groove as a diagnostic feature of Dipturus.

A long and stout rostrum is considered by McEACHRAN \& Miyake (1990b) and McEachran \& Dunn (1998) as plesiomorphic within Rajidae. Stehmann (1970), nonetheless, had emphasized the importance of rostrum length in Dipturus taxonomy. CHEN \& Joung (1989) quantified rostral length for Dipturus as 60\% of the total length of neurocranium, setting it apart from Okamejei in which rostral length is clearly less than $60 \%$. Due to the 

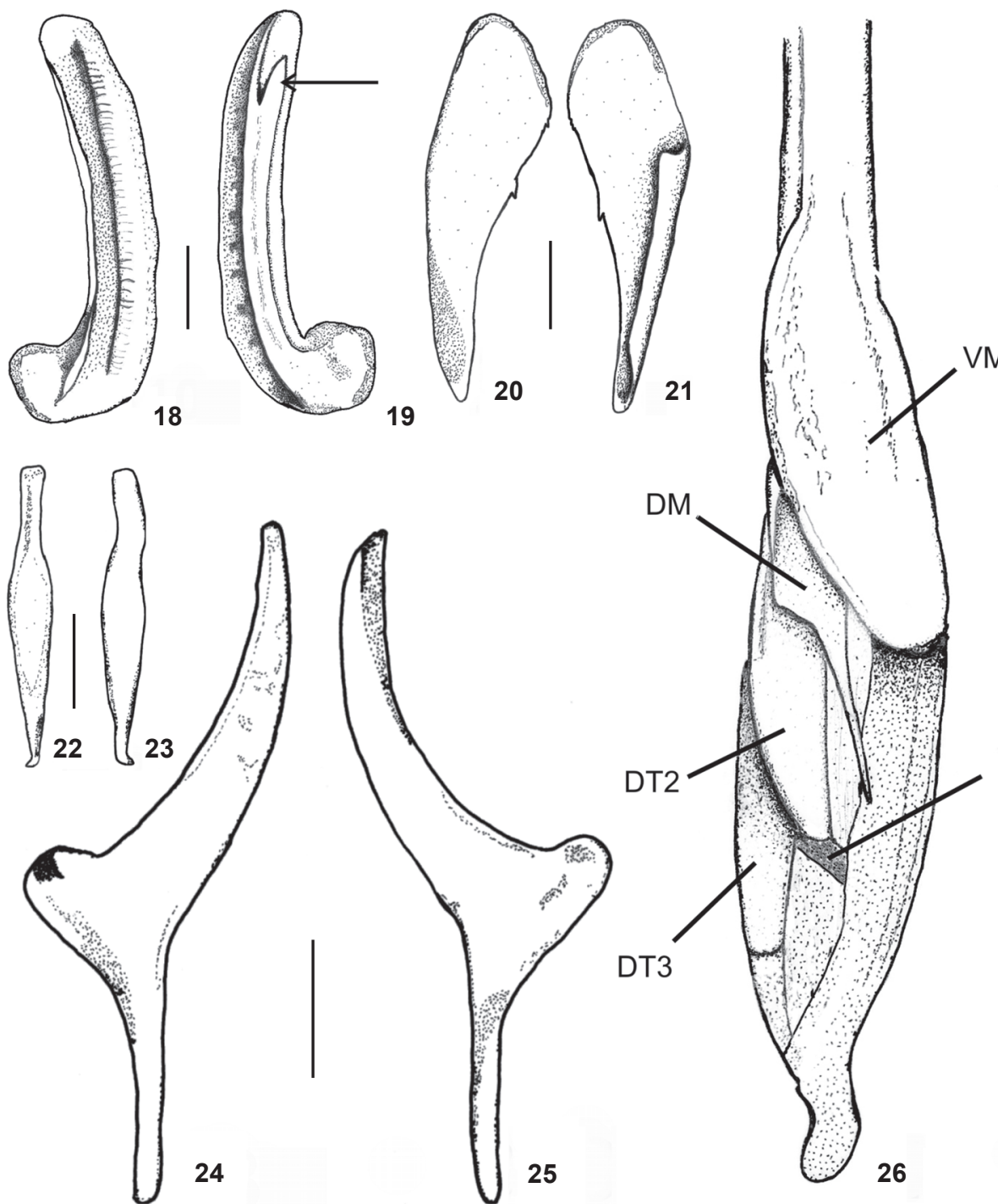

TB

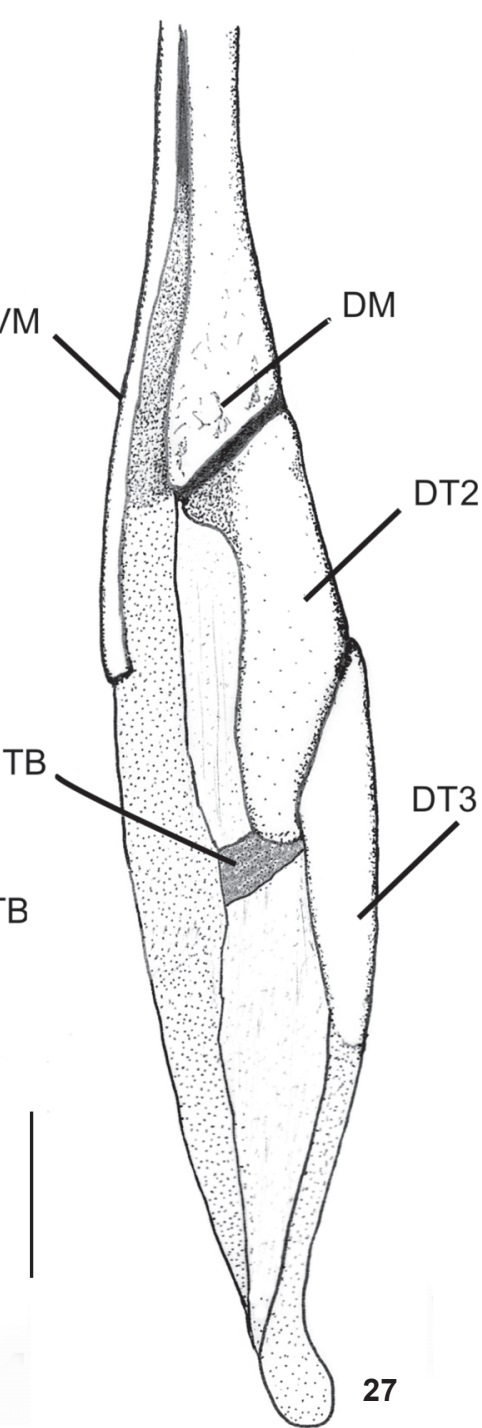

Figures 18-27. Dipturus mennii (UERJ 2103). (18-19) Ventral terminal cartilage: (18) in dorsal view; (19) ventral view. (20-21) Dorsal terminal 1 cartilage: (20) in dorsal view; (21) ventral view. (22-23) Accessory terminal 2 cartilage: (22) in dorsal view; (23) ventral view. (24-25) Accessory terminal 1 cartilage: (24) dorsal view; (25) ventral view. (26-27) Clasper skeleton: (26) ventral; (27) dorsal view, with accessory terminal 1, accessory terminal 2, dorsal terminal 1, and ventral terminal cartilages removed. (DM) Dorsal marginal, (DT2) dorsal terminal 2, (DT3) dorsal terminal 3, (TB) terminal bridge, (VM) ventral marginal. Scale bars: 18-21, 24-25=10 mm, 22-23 = $1 \mathrm{~mm}$, $26-27=20 \mathrm{~mm}$.

relation rostrum/total length of neurocranium, JEONG \& NAKABO (2008) identified their new species D. wuhanlingi as belonging to Dipturus. Dipturus crosnieri also presents this relation (see table 3 of Séret 1989), and so do D. mennii and D. trachyderma. These proportions were also observed by Hulley (1972) in all species of Dipturus from South Africa, except D. pullopunctata (rostrum some $57 \%$ of neurocranium length). In conclusion, rostral proportions may also be derived for Dipturus.

\section{Pectoral girdle}

The pectoral girdle in Rajidae presents basically the same rectangular shape (McEachran \& Compagno 1979, 1982). Leible $\&$ Stehmann (1987) described the pectoral girdle of $D$. trachyderma showing two posterior ventral fenestrae, whereas D. mennii has only one. The presence of two posterior ventral fenestrae seems to be a specific character, as IsHIHARA \& IsHIYAMA (1986) show the pectoral girdle of seven species of Dipturus 
Table VI. Summary of some relevant morphological characters which may distinguish $D$. menni from $D$. trachyderma..

\begin{tabular}{|c|c|c|}
\hline Characters & D. mennii & D. trachyderma \\
\hline Nuchal thorns & $5-7$ & Absent \\
\hline Mediodorsal row & $18-25$ & Absent \\
\hline Lateral tail thorns & $6-26$ & $4-30$ \\
\hline Interdorsal thorns & $1-3$ & $0-4$ \\
\hline Ophthalmic foramen & $\begin{array}{l}\text { Ventrally open groove, associated to ophthalmic } \\
\text { process }\end{array}$ & Fully enclosed, without ophthalmic process \\
\hline Anterior scapulocoracoid fenestra & Circular & Laterally elongated \\
\hline $\begin{array}{l}\text { Posterior ventral fenestra of } \\
\text { scapulocoracoid }\end{array}$ & One fenestra & Two fenestrae \\
\hline Acessory terminal 1 & Anterior segment with regular, smooth surface & Anterior segment with irregular surface \\
\hline Acessory terminal 1 & $\begin{array}{l}\text { Largest segment contacts the ventral terminal } \\
\text { cartilage }\end{array}$ & $\begin{array}{l}\text { Largest segment does not contact the } \\
\text { ventral terminal cartilage }\end{array}$ \\
\hline Ventral terminal & $\begin{array}{l}\text { Anterior and ventral tip short, about the } 1 / 5 \\
\text { length of component }\end{array}$ & $\begin{array}{l}\text { Anterior and ventral tip long, about the } 1 / 3 \\
\text { length of component }\end{array}$ \\
\hline Dorsal terminal 2 & Anterior margin posterior to dorsal terminal 2 & Anterior margin anterior to dorsal terminal 2 \\
\hline Accessory terminal 2 & $\begin{array}{l}\text { Not elongated, twisted at posterior tip of } \\
\text { accesory terminal } 2\end{array}$ & $\begin{array}{l}\text { Elongated, only slightly twisted at posterior } \\
\text { tip of acessory terminal } 2\end{array}$ \\
\hline Terminal bridge & $\begin{array}{l}\text { Short, arising between the dorsal terminal } 2 \text { and } \\
\text { dorsal teriminal } 3\end{array}$ & $\begin{array}{l}\text { Elongated, wedged between dorsal terminal } \\
1 \text { and dorsal terminal } 2\end{array}$ \\
\hline
\end{tabular}

from North Pacific, all presenting just one ventral fenestra. The shape and size of the anterior and posterior fenestrae can also vary greatly according to species. The anterior fenestra of $D$. trachyderma, according to Leible \& STEHMANN (1987), suffers a constriction due to the elongation of the procondyle and mesocondyle, unlike in D. mennii in which the anterior fenestra is quite circular.

\section{Claspers}

Dipturus mennii and D. trachyderma have subtle, but reliable differences in clasper skeleton. Leible \& SteHmann (1987) gave a detailed description of the external and internal structures of the mixopterigium of D. trachyderma. In D. trachyderma these authors showed that the anterior segment of the accessory terminal 1 cartilage has an irregular surface, different from D. mennii in which it is entirely smooth. In D. mennii the largest segment of the accessory terminal 1 contacts the ventral terminal cartilage, a condition also seen in D. trachyderma, $D$. batis, and D. oxyrinchus, as demonstrated by Leible \& STEHMAnN (1987) and Stehmann (1970). Ishiyama (1958) showed that the same condition occurs in Japanese Dipturus species. Hulley (1972), however, found that in the South African Dipturus doutrei and $D$. lanceorostrata the ventral terminal cartilage does not firmly articulate with the accessory terminal 1 .

In $D$. trachyderma, the ventral terminal cartilage is situated more anteriorly (Leible \& STEHMANN 1987), contacting the ventral marginal to a greater extent than in D. mennii, in which the ventral terminal is more posteriorly positioned and so con- tacts the accessory terminal 1 cartilage more than it does the ventral marginal cartilage. The ventral terminal cartilage of $D$. mennii presents an anteroventral and sharp segment (Fig. 19, see arrow) that is about $1 / 5$ of the total length of the component. In $D$. trachyderma, this segment is greater, achieving about $1 / 3$ of the length of the ventral terminal (as inferred from LeIBLE \& STehmann 1987). Furthermore, the posterior portion of the ventral terminal is much more spatulate in $D$. trachyderma than in D. mennii.

According to Leible \& STehmann (1987), the accessory terminal 2 cartilage in $D$. trachyderma is elongated, rod-shaped, and slightly twisted, with a flattened distal end, but exactly where this torsion takes place is not so clear. The torsion in $D$. mennii occurs only at the posterior tip of the accessory terminal 2 cartilage (Figs 22 and 23), but not as much as in Dipturus crosnieri, in which this cartilage is highly twisted distally, appearing J-shaped (SÉRET 1989). This cartilage can also present a well developed and posteriorly pointed process in some Japanese Dipturus (e.g. D. macrocauda and D. gigas), Okamejei (e.g. O. hollandi and O. kenojei), according to IshiYama (1958), and $D$. pullopunctata (Hulley 1972). The accessory terminal 2 cartilage therefore varies significantly among species and may have great importance in Dipturus taxonomy.

The dorsal terminal 1 cartilage is somewhat similar in $D$. trachyderma and D. mennii, but in the former species it reaches farther anteriorly (beyond the level of the dorsal terminal 2, whereas in D. mennii its anterior margin is posterior to dorsal 
terminal 2), and is relatively wider posteriorly. According to Leible \& STEHMANN (1987) the shape of this cartilage is very similar in all representatives of Dipturus, including the lack of the proximal support (or proximal edge) for the insertion of the dilator muscle, as was also confirmed by Hulley (1972) for $D$. pullopunctata, D. lanceostrata, and $D$. doutrei.

The dorsal terminal 2 cartilage is more slender in $D$. trachyderma in comparison to the dorsal terminal 2 of D. menni. According to Hulley (1972), in the South African D. doutrei and D. pullopunctata, a short, cartilaginous bridge (the terminal bridge) is well-developed, connecting the dorsal terminal 2 to the axial cartilage. In D. mennii the terminal bridge is short and arises between the dorsal terminal 2 and dorsal terminal 3, attaching both cartilages to the axial cartilage, whereas in D. trachyderma the terminal bridge is much more elongated and wedged in between dorsal terminals 1 and 2 (Leible \& Stehmann 1987).

In conclusion, Dipturus mennii and D. trachyderma are clearly distinct species. The main diagnostic characters that separate them are found in squamation patterns (nuchal and mediodorsal thorns, number of thorns on lateral tail), neurocranial features (ophthalmic foramen, ophthalmic process), anterior and posterior ventral fenestra of scapulocoracoid, and mixopterigial skeleton (accessory terminals 1 and 2, terminal bridge, ventral terminal, dorsal terminals 1 and 2). However, there is a significant gap in our knowledge concerning the synarcual cartilage and gill arches among species of Dipturus, and therefore descriptive studies of these elements are needed in addition to those typically done on the neurocranium and clasper. Furthermore, a general revision of the diagnostic characters of Dipturus and its included species are necessary in light of the morphological similarities with the putatively closely related genera Okamejei and Zearaja; however, the anterior rostral groove, elevated rostral proportions, and specific configuration of the ventral terminal cartilage may indeed be derived characters for Dipturus.

\section{ACKNOWLEDGEMENTS}

We thank C.M. da Cunha and C.M. Vooren for the donation of specimens used in this study, and H.R.S. Santos for suggestions and discussion. The program PROCIÊNCIA/FAPERJ is acknowledged for grants awarded to the second author. The third author is supported by research fellowships from CNPq (303061/2008-1) and Fapesp (2010/51193-5).

\section{LITERATURE CITED}

Carvalho, M.R. DE; U.L. Gomes \& O.B.F. Gadig. 2005. Description of a new species of skate of the genus Malacoraja Stehmann, 1970: the first species from the southwestern Atlantic Ocean, with notes on generic monophyly and composition (Chondrichthyes: Rajidae). Neotropical Ichthyology 3 (2): 239-258.
Carvalho, M.R. DE; U.L. Gomes \& J.D. McEachran. 2006. First report and description of a legskate, genus Cruriraja, from southwestern Atlantic Ocean (Chondrichthyes: Rajidae). Cybium 30 (4): 343-354.

Compagno, L.J.V. 1988. Sharks of the order Carchariniformes. New Jersey, Princeton University Press, 486p.

Compagno, L.J.V. 1999. Checklist of living elasmobranchs, p. 471-498. In: W.C. Hamletт (Ed.). Sharks, skates, and rays. The biology of the elasmobranch fishes. Baltimore, John Hopkins University Press, 515p.

Compagno, L.J.V. 2005. Checklist of living Chondrichthyes, p. 501-548. In: W.C. HAMLETT (Ed.). Reproductive biology and phylogeny of chondrichthyes: sharks, batoids, and chimaeras. Enfield, Science Publishers, 503-548.

Chen, C.T. \& S.J. Joung. 1989. Fishes of the Genus Raja (Rajiformes: Rajidae) from Taiwan. Journal of Taiwan Museum 42 (2): 1-12.

EBERT, D.A. \& L.J.V. COMPaGNo. 2007. Biodiversity and systematics of skates (Chondrichthyes: Rajiformes: Rajoidei). Environmental Biology of Fishes 80: 111-124.

EL-Toubi, M.R. \& A.R. Hamdy. 1959. Studies on the head skeleton of Rhinobatus halavi, Rhynchobatus djiddensis and Trygon kuhlii. Publications of Marine Biological Station, Al Ghardaqa (Red Sea), Cairo University, 10: 3-39.

Figueiredo, J.L. 1977. Manual de peixes marinhos do sudeste do Brasil. 1. Introdução. Cações, raias e quimeras. São Paulo, Museu de Zoologia da Universidade de São Paulo, 104p.

Gomes, U.L. \& S.R. Costa. 2003. New records of the thintail skates Dipturus leptocauda (Rajidae, Rajinae, Rajini), with notes on its taxonomy. Biociências 11 (1): 91-95.

Gomes, U.L. \& C. Paragó. 2001. Espécie nova de rajídeo (Chondrichthyes, Rajiformes) do Atlântico sul Ocidental. Boletim do Museu Nacional, Zoologia 448: 1-10.

Gomes, U.L. \& C. PARAGó. 2005. A utilização da distribuição dos poros de canais de muco e da coloração ventral como caracteres taxonômicos em Riorajini (Chondrichthyes, Batoidea, Rajidae). Biociências 13 (1): 55-62.

Gomes, U.L. \& S.S. PICADo. 2001. Distribution of the species of Dipturus Rafinesque (Rajidae, Rajinae, Rajini) off Brazil and first record of the Caribbean skate D. teevani (Bigelow \& Schroeder) in the Western South Atlantic. Revista Brasileira de Zoologia 18 (1): 171-185.

Gomes, U.L.; C. WinKelstein \& W. SouZA-Lima. 1997. Estudo da cartilagem sinarcual cérvico-torácica em rajídeos (Batomorphii, Rajiformes) da região sul e sudeste do Brasil. Anais da Academia Brasileira de Ciências 69 (1): 95-107.

Hubbs, C.L. \& R. Ishiyama. 1968. Methods for the taxonomic study and description of skates (Rajiformes). Copeia 3: 483491.

Hulley, P.A. 1972. The origin, interrelationships and distribution of Southern African Rajidae (Chondrichthyes, Batoidei). Annals of South African Museum 60 (1): 1-103.

IsHIYAMA, R. 1958. Studies on the rajid fishes (Rajidae) found in 
the water around Japan. Journal of the Shimonoseki College of Fisheries 7: 193-394.

Ishinara, H. 1987. Revision of the western North Pacific species of the genus Raja. Japanese Journal of Ichthyological 34 (3): 241-285.

Ishinara, H. \& R. Ishiyama, 1986. Systematics and Distribution of the Skates of the North Pacific (Chodrichthyes, Rajoidei), p. 269-280. In: T. Uyeno; R. Arai; T. Taniuchi \& K. Matsuura (Eds). Indo-Pacific Fishes Biology: Proceedings of the Second International Conference on Indo-Paific Fishes. Tokyo, Ichthyological Society of Japan, 985p.

Jeong, C-H. \& T. NAKabo. 2008. Dipturus wuhanlingi, a new species of skates (Elasmobranchii: Rajidae) from China. Ichthyological Research 55 (2): 183-190.

KreffT, G. 1968. Neue und erstmalig Knorpelfische aus dem Archibental des Südwestatlantiks, einschliesslich einer Diskussion einiger Etmopterus - Arten südlicher Meere. Archiv für Fischereiwissenschaft 19 (1): 1-42.

Krefrt, G. \& M. Stehmann. 1974. Ergebnisse der Forchungsreisen des FFS "Walther Herwig" nach Südamerika. XXXIII. Raja (Rajella) sadowskii spec. nov. (Chondrichthyes, Batoidei, Rajidae) ein weiteres neuer Roche von Südwestatlantischen Kontinentablang. Archiv für Fischereiwissenschaft 25: 33-50.

Krefft, G. \& M. Stehmann. 1975. Ergebnisse der Forchungsreisen des FFS "Walther Herwig" nach Südamerika. XXXVI. Zwei weitere neue Rochenarten aus dem Sudwestatlantik: Raja (Dipturus) leptocauda und Raja (Dipturus) trachyderma spec. nov. (Chondrichthyes, Rajidae). Archiv für Fischereiwissenschaft 25: 77-97.

LAST, P.R. 2008. New short-snout members of the skate genus Dipturus (Rajoidei: Rajidae) from Australian seas, p. 53-98. In: P.R. Last; W.T. White; J.J. Pogonoski \& D.C. Gledhill (Eds). Descriptions of New Australian Skates (Batoidea: Rajoidei). Canberra, CSIRO Marine \& Atmospheric Research Paper 021, 182p.

Last, P.R. \& D.C. Gledhill. 2007. The Maugean Skate, Zearaja maugeana sp. nov. (Rajiformes: Rajidae) - a micro-endemic, Gondwanan relict from Tasmanian estuaries. Zootaxa 1494: 45-65.

Last, P.R.; W.T. White. \& J.J. Pogonoski. 2008. New skates of the genus Dipturus (Rajoidei: Rajidae) from Australian Seas, p. 9-51. In: P.R. Last; W.T. White; J.J. Pogonoski \& D.C. Gledhill (Eds). Descriptions of New Australian Skates (Batoidea: Rajoidei). Hobart, CSIRO Marine \& Atmospheric Research Paper 021, 182p.

Leible, M.D. 1987. Descripción taxonimica de juveniles y adultos de Raja (Dipturus) flavirostris Philippi, 1892 (Rajiformes, Rajidae), capturados frente a la costa de Chile Central. Gayana Zoologia 51 (1-4): 131-176.

Leible, M.D. 1988. Revisión de métodos para estudios taxonomicos de rayas (Rajiformes, Rajidae). Gayana Zoologia 52 (1-2): 15-93.

Leible, M.D. \& M.F.W. Stehmann. 1987. First records of Raja
(Dipturus) trachyderma Krefft \& Stehmann, 1975 from Southeastern Pacific off Chile, with first descriptions of its clasper and additional skeletal and morphological details (Pisces, Rajiformes, Rajidae). Studies on Neotropical Fauna and Environment 22 (4): 169-188.

McEachran, J.D. 1982. Revision of the American skate genus Sympterygia (Chondrichthyes, Rajiformes). Copeia 1982 (4): 867-890.

McEachran, J.D. 1983. Results of the research cruises of FRV "Walther Herwig" to South America. LXI: Revision of the South American skate genus Psammobatis Günther, 1879 (Elasmobranchii, Rajiformes, Rajidae). Archiv für Fischereiwissenschaft 34: 23-80.

McEachran, J.D. \& L.J.V. Compagno. 1979. A further description of Gurgesiella furvenscens, with comments on the interrelationships of Gurgesiellidae and Pseudorajidae. (Pisces, Rajoidei). Bulletin of Marine Science 29 (4): 530-553.

McEachran, J.D. \& L.J.V. Compagno. 1982. Interrelationships of and within Breviraja based on anatomical studies (Pisces, Rajoidei). Bulletin of Marine Science 32 (2): 399-425.

McEachran, J.D. \& T. Miyake. 1990a. Phylogenetic Interrelationships of skates: a working hypothesis (Chondrichthyes, Rajoidei), p. 285-304. In: C.H.L. Pratt Jr; S.H. Gruber \& T. TANIUCHI (Eds). Elasmobranch as living resources: advances in the biology, ecology, systematics and the status of the fisheries. Seattle, NOAA Technical Report NMFS 90, 517p.

McEachran, J.D. \& T. Miyake. 1990b. Zoogeography and Bathymetry of skates (Chondrichthyes, Rajoidei), p. 305325. In: C.H.L. Pratt JR; S.H. Gruber \& T. Taniuchi (Eds). Elasmobranch as living resourses: advances in the biology, ecology, systematics and the status of the fisheries. Seattle, NOAA Technical Report NMFS 90, 517p.

MCEAChran, J.D. \& K.A. Dunn. 1998. Phylogenetic analysis of skates, a morphologically conservative clade of elasmobranchs (Chondrichthyes, Rajidae). Copeia 1998 (2): 271-290.

McEachran, J.D. \& M.R. de Carvalho. 2002. Batoid fishes, p. 507589. In: K.E. CARPENTER (Ed.). The living marine resources of the Western Central Atlantic. Volume 1: introduction, molluscs, crustaceans, hagfishes, sharks, batoid fishes and chimaeras. FAO Species Identification Guide for Fisheries Purposes. Rome, FAO and American Society of Ichthyologists and Herpetologists Special Publication 5, 600p.

Menni, R.C. 1971. Anatomia del mixopterigio y posicion sistematica de Raja (Dipturus) flavirostris Phillipi, 1892. Neotropica 17 (52): 39-43.

Menni, R.C. 1972a. Anatomia del mixopterigio y diferencias especificas en los genros Psammobatis y Sympterygia (Chodrichthyes, Rajidae). Neotropica 18 (56): 73-80.

MennI, R.C. 1972b. Raja (Atlantoraja) subgen. nov. y lista critica de los Rajidae argentinos (Chondrichthyes, Rajiformes). Revista del Museo de La Plata 11: 165-173.

MenNi, R.C. 1973. Rajidae del litoral bonaerense. I. Especies de los generos Raja, Bathyraja y Sympterigia (Chondrichthyes). 
Physis 32: 413-439.

Menni, R.C. \& A.E. GoszTonyi. 1977. Nuevas localidades para Raja trachyderma y Lamna nasus (Chondrichthyes, Rajidae y Lamnidae). Neotropica 28 (69): 65-68.

Menni, R.C. \& M.F.W. Stehmann. 2000. Distribution, environment and biology of batoid fishes off Argentina, Uruguay and Brazil. A review. Revista del Museo Argentino de Ciencias Nataturales n.s. 2 (1): 69-109.

SAdowsky, V. \& R.C. Menni. 1974. Sobre Raja platana Günther, 1880 (Chondrichthyes, Rajidae). Physis 33 (86): 23-32.

SÉret, B. 1989. Deep water skates of Madagascar. Part 3. Rajidae
(Pisces, Chondrichthyes, Batoidea). Raja (Dipturus) crosnieri sp. nov. Cybium 13 (2): 115-130.

Séret, B. \& P.R. LASt. 2008. A new Australian skate of the genus Dipturus (Rajoidei: Rajidae), p. 99-108. In: P.R. LAsT; W.T. White; J.J. Pogonoski \& D.C. Gledhill (Eds). Descriptions of New Australian Skates (Batoidea: Rajoidei). Hobart, CSIRO Marine \& Atmospheric Research Paper 021, 182 p.

Stehmann, M.F.W. 1970. Vergleichend morphologische und anatomische Untersuchungen zur Neuordnung der systematik der Norostatlantischen Rajidae (Chondrichthyes, Batoidei). Archiv für Fischereiwissenschaft 21: 73-164.

Submitted: 01.XII.2009; Accepted: 26.IX.2010.

Editorial responsibility: Wolmar B. Wosiacki 